\title{
Digital Technologies Development in the Educational Process of Ecology and Industrial Safety Department, Bauman Moscow State Technical University
}

\author{
Ekaterina S. Antonova ${ }^{1 *}$, Aleksey S. Kozodaev ${ }^{1}$, Sergey D. Morozov ${ }^{1}$, Yury V. Plastinin ${ }^{1}$, \\ and Elena N. Simakova ${ }^{1}$ \\ ${ }^{1}$ Bauman Moscow State Technical University, 2nd Baumanskaya str., 5/1, 105005, Moscow, Russia
}

\begin{abstract}
The report gives current status overview of how the digital technologies integration evolves in the educational process as well as gives brief overview of the whole educational activities of Ecology and Industrial Safety department in Bauman Moscow State Technical University. The most attention is payed to the development and introduction of the online course Life safety in the educational process and done using Open BMSTU platform and the educational portal of the department e9.bmstu.ru. The contents and the structure of course are presented. The peculiarities of the work at online course are pointed out. The forms of online presentations, access for authorized teachers and students and control tests are considered. The procedure of the creation of video lectures and introductions to laboratory works is briefly depicted. Other components of the educational portal including online video library of the department, laboratory works online timetable, life safety course online introduction videos to the laboratory works are also presented.
\end{abstract}

\section{Introduction}

This work covers the current results of the digital technologies integration into the educational process and the overview of the whole educational activities of Ecology and Industrial Safety department in Bauman Moscow State Technical University. The digital technologies integration project was developed by Y. V. Plastinin in 2014-2015 years. The update of Ecology and Industrial Safety department official website: http://e9.bmstu.ru (alias: mhts.ru, which represents the previous famous name of our university: Moscow High Technical School) was the reason of this project creation.

According to the implemented changes the updated website provides the access to:

- Youtube channel [1] of the department that contains the best reports from conferences (1), graduate qualification works (2), main courses online lectures (3), online introduction videos to laboratory works (4);

- presentations of lectures and seminars (5);

* Corresponding author: e.s.antonova@ bmstu.ru 
- educational-methodical material (6);

- other informational materials (7).

Moreover, the project includes the development of mobile applications (8), laboratory works online timetable management system (9). The latter was proposed by M. V. Simakov.

The online lectures (3) and presentations (5) development was integrated into The Program of the online courses development and integration into the educational process in Bauman Moscow State Technical University based on the Open BMSTU [2] platform in 2018-2019. The results of the elements (3) and (5) integration into the educational process of spring 2018/2019 semester are described in more details below.

Let us look briefly into the other elements of the project.

\section{Main part}

Elements (1)-(2) represent online video library of the department. The creation of Crisis Situations Management Center (CSMC) allowed to record and store conferences reports, graduate qualification works on video server $[3,4,5]$. These materials were edited and uploaded on the Youtube channel [1]. They can be used during consultations, students' research work, preparation to student contests.

Elements (6)-(7) are the basic ones to be used for high-class university websites. It is important to mention that materials were being collected during all these years from the website creation time in 2000 up to now. It is crucial for materials to be continuously updated.

Laboratory works online timetable management system for Life Safety course was developed and integrated into the educational proccess in 2018-2019 [6]. The students authorized by lecturers register their groups for the laboratory works: two times during the semester. The system administrator sets the critical number of students in the group while when being exceeded automatically divided into two groups. The administrator also sets the planned number of hours for each lecturer, so each lecturer can keep control of the total number of hours. If there is no any record in the timetable made by students the lecturer cannot confirm the laboratory work. The timetable of autumn semester 2019/2020 was the first pilot to be done though the introduced system. The system is not linked to particular course and can be used for laboratory works timetable management for any course.

Life safety course online introduction videos to the laboratory works (4) were created in 2018 [7]. Students of the department took part in the development of these videos. The created videos do not substitute printed methodical materials because they do not contain the work order instructions. They substitute the introduction and theoretical part. The authors of printed methodical materials took part in the development of the scenarios of these videos.

Video was created according to the approved story-board scenario in Adobe Premier application. The audio coverage (text) was done by the students of the department.

The online lectures (3) of the course Life safety was developed according to the Program of the development and introduction of online courses into the educational process of Bauman Moscow State Technical University. Online lectures were created the same way as the online introduction videos (4). Story-board scenarios of lectures were devoted to different topics such as noise protection, vibration protection, illumination and so on and were created by the leading specialists of the department and compiled and edited by Y. V. Plastinin, who has great experience in the development of multimedia projects. Students of the department took part in the process as well. The scenario included text of the lecture linked to the illustrations: photo, video, pictures, graphics, formulas and so on. Each scenario was reviewed and corrected to be finally signed off. The videos of A. S. Kozodaev 
lectures were recorded in a studio with special green background. Then the video was edited using keying method and synchronized with frames of the illustrations in Adobe Premier application.

The authors of the online course could not use the widely spread textbook «Life safety» under the edition of Belov S. V. [8] written in our department mostly by the same authors of online course. The key reason was that multimedia presentation requires another approach for the material presentation. At the same time authors of online course leveraged the great experience gained during teaching the course of Life safety in the department. Teaching experience of the authors from Bauman Moscow State Technical University [911] and authors from international institutions [12-20] was also considered. It is important to mention that the course creation was initiated by S.V. Belov (1932-2013), who was the head of our department from 1976 till 2007 [21].

Life safety Online course consists of 16 lectures and is available on the youtube channel and the department website [1,22]. It is also available on the platform Open BMSTU [2].

More than $40 \%$ of the students watched these lections at the beginning of the course in the 2018/2019 which is quite high.

The Life safety course ppt-presentations of lectures and seminars (5) unlike online lectures have to consider the specialization of students. The webpages of the course are available only to authorized students and are created individually for each lecturer [23]. The lecturer gives the access to his personalized page at the beginning of the course and closes access when the course ends. Besides the presentations of lectures and seminars the lecturer can upload any supplementary material, such as summary of the most complicated lectures, tasks for the seminars and examples of their solutions.

The choice of Life safety online course realization among of all others courses of the department, is quite evident.

According to the Federal State of Educational Standards for Higher Education the Life safety course has to be mandatory course for all students and has to be part of the main educational plan for bachelors and specialists of all specializations.

Nowdays many universities in Russian Federation have developed their own online courses of this discipline (SPbPU, NUST MISIS, TSU (Tomsk), SPbU and so on).

NUST MISIS, TSU (Tomsk), SPbU have included their courses to the National Platform of Open Education.

The main purpose of studying the Life safety course is the development of the professional safety culture (noxological culture), which means:

- the willingness and ability of the individual to use the acquired combination of knowledge, abilities and skills for the safety provision in the field of professional activity;

- the way of thinking and value prioritization in which safety is considered as priority.

The content of online course corresponds the requirements of Federal State Educational Standards of Higher Education, Self established educational standards of higher education, Approximate program of the course, work programs of Life safety course of Bauman Moscow State Technical University.

The Life safety course is taught according to the educational programs of bachelors and specialists for all specializations and consists of three modules:

1)A person and technosphere;

2)The identification of hazards, methods and ways of protection;

3)Emergency and civil defense.

The structure of the course is presented in the Fig. 1. 


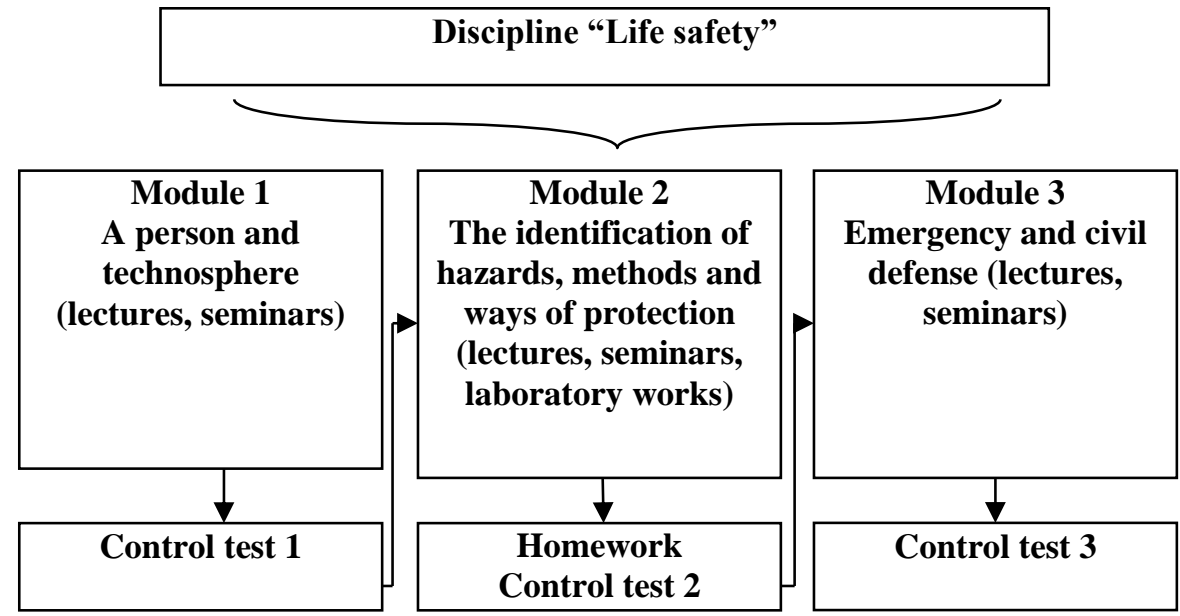

Fig. 1. The structure and contents of discipline «Life safety» in Bauman Moscow State Technical University.

The total hours of the course piloted online in 2018/2019 was 144 hours and included auditory work: lectures -34 hour, seminars -17 hours, laboratory works -17 hours. Check points included 3 control tests (in each module) and 1 homework (in the second module).

The contents of the course is presented in table 1.

Table 1. The contents of the discipline «Life safety».

\begin{tabular}{|c|l|}
\hline № & \multicolumn{1}{|c|}{ Module/contents } \\
\hline 1 & \multicolumn{1}{|c|}{ A person and technosphere } \\
\hline L 1.1 & $\begin{array}{l}\text { Main terms and definitions in the field of life safety (habitat, hazard, safety). } \\
\text { Interaction basics in a system «Person - habitat». }\end{array}$ \\
\hline L 1.2 & $\begin{array}{l}\text { Life safety management: classification of industrial hazards, hazards of the } \\
\text { environment, hazards of emergency, main normative documents of labour and } \\
\text { environment protection, safety management in case of emergency. }\end{array}$ \\
\hline L 1.3 & $\begin{array}{l}\text { Investigation of industrial accidents: normative documents, classification of } \\
\text { accidents, accidents that are to be investigated, the duties of employer, procedure of } \\
\text { the commission formation and investigation of such accidents, the forms of the } \\
\text { documents for results of the investigation. }\end{array}$ \\
\hline S 1.1 & $\begin{array}{l}|c| \\
\text { Index of negativeness of habitat: statistic index of injuries, environmental index of } \\
\text { negativeness. }\end{array}$ \\
\hline 2 & \multicolumn{1}{|c|}{ The identification of hazards, methods and ways of protection. } \\
\hline L 2.1- & $\begin{array}{l}\text { Lectures } \\
\text { Main principles of protection from physical factors: main characteristics of vibration } \\
\text { and their units, classification of vibration, regulation of vibration, influence of } \\
\text { vibration on people, sources of vibration, methods of protection from vibration; main } \\
\text { characteristics of the acoustic field, classification of noise, peculiarities of the } \\
\text { influence on people of acoustic vibrations of various frequency ranges, regulation of } \\
\text { noise, professional diseases influenced by noise , methods of protection from noise. }\end{array}$ \\
\hline
\end{tabular}


Table 1. (Continued) The contents of the discipline «Life safety».

\begin{tabular}{|c|c|}
\hline $\begin{array}{l}\mathrm{L} 2.5- \\
2.6\end{array}$ & $\begin{array}{l}\text { Normalization of microclimate parameters and the condition of the air: air pollutants } \\
\text { and negative consequences of their influence, the air quality in the production area, } \\
\text { peculiarities of air contamination, professional diseases, intoxications, optimal and } \\
\text { allowable microclimate parameters, their regulation, heat exchange between person } \\
\text { and environment, thermoregulation, the contents of chemical substances in the air, } \\
\text { maximum allowable concentration for atmospheric air and air of production area, } \\
\text { maximum allowable concentration for the combined action of the substances, } \\
\text { classification of ventilation systems and their operating requirements, main methods } \\
\text { and technologies of air purification, their choice and calculation, personal protective } \\
\text { equipment. }\end{array}$ \\
\hline L 2.7 & $\begin{array}{l}\text { Electromagnetic radiation: natural and artificial sources of electromagnetic radiation, } \\
\text { classification of electromagnetic radiation, influence of electromagnetic radiation on } \\
\text { people, diseases caused by electromagnetic radiation, regulation of electromagnetic } \\
\text { radiation, the use of electromagnetic radiation in engineering, information and } \\
\text { medical technologies, protection from electromagnetic radiation. } \\
\text { UV-light: sources of UV-light in biosphere and technosphere, influence on people, } \\
\text { regulation, methods of protection from UV-light. }\end{array}$ \\
\hline L 2.8 & $\begin{array}{l}\text { Laser: peculiarities and characteristics, frequency ranges, main parameters and } \\
\text { classification, influence on people and principles of determination of maximum } \\
\text { allowable levels, use of laser in engineering, information and medical technologies, } \\
\text { methods of protection. }\end{array}$ \\
\hline L 2.9 & $\begin{array}{l}\text { Industrial illumination: classification of systems of industrial illumination, regulation, } \\
\text { methods of calculation. }\end{array}$ \\
\hline L 2.10 & $\begin{array}{l}\text { Electricity: classification of electrical networks, parameters and sources of electrical } \\
\text { hazard, influence of electrical current on a person, electrical safety methods. }\end{array}$ \\
\hline & Seminars \\
\hline S 2.1 & Vibration protection. Noise protection. \\
\hline $\mathrm{S} 2.2$ & Calculation of ventilation system \\
\hline S 2.3 & Calculation of illumination system \\
\hline S 2.4 & Electrical safety \\
\hline & Control test №2 \\
\hline & Laboratory works \\
\hline LW 1 & Vibration protection \\
\hline LW 2 & Noise protection \\
\hline LW 3 & Parameters of microclimate \\
\hline LW 4 & Protection from infrared radiation \\
\hline LW 5 & Research of natural light \\
\hline LW 5 & Research of industrial illumination \\
\hline LW 6 & Protection from laser \\
\hline LW 7 & Electrical safety \\
\hline 3 & Emergency and civil defense \\
\hline L 3.1 & $\begin{array}{l}\text { Main principles of protection from chemical hazards: chemical control measures and } \\
\text { methods of protection, devices for chemical control, personal protective equipment. }\end{array}$ \\
\hline $\begin{array}{c}\text { L 3.2- } \\
3.2\end{array}$ & $\begin{array}{l}\text { Main principles of protection from physical hazards: system of fire safety, system of } \\
\text { fire prevention, evacuation, fire fighting basics, extinguishing agents. }\end{array}$ \\
\hline \multirow[t]{2}{*}{ L 3.3} & $\begin{array}{l}\text { Main principles of protection from ionizing radiation: types of ionizing radiation, } \\
\text { main terms of radiation safety, sources and characteristics of ionizing radiation, } \\
\text { biological influence of ionizing radiation on people and environment, principle of } \\
\text { regulation, methods of protection. }\end{array}$ \\
\hline & Seminars \\
\hline S 3.1 & $\begin{array}{l}\text { Assessment of chemical situation: initial data for calculation, basic principles of the } \\
\text { calculation, calculation methodic. }\end{array}$ \\
\hline S 3.2 & Assessment of fire at fire risk objects. \\
\hline
\end{tabular}


There were 2 ways of how the online course was used by different lecturers:

1) online lectures, presentations and summaries were available for students before the lessons; presentation were used during the lesson; online lectures were demonstrated fully or partly;

2) online lectures were available for students before the lessons, presentations and summaries were available only after the lessons; presentations were used as supplementary material in the usual lecture; online lectures were not demonstrated during the lessons.

The best approach can not be defined yet as the comparison of students results from different groups was not carried out.

The check points were done in the test format on the platform Open BMSTU [2]. The tasks and questions were developed based on the ones already shown during seminars and topics covered during lectures.

The students had access to the tests via their accounts, being active during the semester. By the way, in our opinion the double authorization is more effective: the authorization of the device used for doing tests and the authorization of student. In our opinion the use of the smartphones for such activity is not appropriate. Moreover, the test system has to be modified: the option of the second try test is to be added. The availability of the test that can be done for the second time has to be controlled by the lecturer. The results of the tests should have the different max points as it is the second try.

The homework and laboratory works were almost unchanged in comparison to the usual way of teaching the course. Although the students had the opportunity to get ready for the laboratory works by watching online introduction videos [7].

The lectures and seminars required computers and devices for slides and video demonstration (for example, projector). Computer classes were required for the control tests. By the way, the necessity of the blackboard has not disappeared as the students often have questions that demand the detailed illustrative response that can de hardly predicted.

Unlike the usual lessons, online seminars were carried out in different classes: control tests in computer classes, ordinary seminars in ordinary classes which led to some organization problems.

\section{Conclusions}

The pilot of the online course introduction in the educational process continues in 20192020: the number of students and lecturers, participating in experiment, grows, the presentations are constantly improved, updated and adopted to particular specialization of the students. The next special Ecology of biosphere course is being developed at the moment.

\section{References}

1. Channel of the Department «Ecology and industrial safety» BMSTU, https://www.youtube.com/channel/UCGbtQzQkN92X8XsGNbO3cNg, last accessed 2019/10/29

2. Open BMSTU, open.bmstu.ru, last accessed 2019/10/29

3. V.A. Devisilov, A.A. Aleksandrov, S.P. Sushchev, A.N. Kalaydov and D.O. Kopytov, The paper analyzes teaching techniques applied by the Department of Ecology and Industrial Safety of Bauman Moscow State Technical University (BMSTU) for students of "Safety in Technosphere" ("Critical Incidents Response" major), Technique is based on contemporary computer technology and the developed complex of teaching programs, Tehnosfernaya bezopasnost' 34, pp. 55-59 (2014) 
4. A.A. Aleksandrov, V.A. Devisilov, S.P. Sushchev, D.O. Kopytov, Capabilities and application of the crisis management center of BMSTU for teaching in the field of protection from emergency situations, Materials of the III International scientific and practical conference "Modern problems of life safety: present and future", part II, pp.7-18 (2014)

5. Official site of the Department «Ecology and industrial safety» BMSTU: functions of the crisis management center, http://mhts.ru/centr-upravlenija-v-krizisnyh-situacijahfunkcii.html, last accessed 2019/10/29

6. Official site of the Department «Ecology and industrial safety» BMSTU: Schedule of laboratory workshop (first semester of the 2019/2020 academic year), http://mhts.ru/schedule/, last accessed 2019/10/29

7. Official site of the Department «Ecology and industrial safety» BMSTU: Online introductions to lab works, http://mhts.ru/study-laboratornyi-praktikumobsh_lab_praktik_about.html, last accessed 2019/10/29

8. S.V. Belov, Health and safety, Vjshaya shkola Publ., Moscow (2007)

9. I. Titov, E. Titov, Delivering video content in educational platforms, 2013 International Conference on Interactive Collaborative Learning (ICL) IEEE (2013). doi: 10.1109/ICL.2013.6644692

10. T.P. Skorikova, S.S. Khromova, N.V. Dneprovskaya, Distance Learning in Scientific and Professional Fields of Communication (Interdisciplinary Approach), International Journal of Environmental and Science Education, 11(10), pp. 3467-3476 (2016)

11. N.M. Mezhennaya, O.V. Pugachev, On the results of using interactive education methods in teaching Probability Theory, Problems of Education in the 21st Century, 76(5), pp. 678-692 (2018)

12. A. Loveless, Technology, pedagogy and education: reflections on the accomplishment of what teachers know, do and believe in a digital age, Technology, Pedagogy and Education, 20(3), pp. 301-316 (2011). doi: 10.1080/1475939X.2011.610931.

13. N. Selwyn, Looking beyond learning: Notes towards the critical study of educational technology, Journal of computer assisted learning, 26(1), pp. 65-73 (2010). doi: 10.1111/j.1365-2729.2009.00338.x

14. H. Beetham, R. Sharpe, An introduction to rethinking pedagogy for a digital age, Rethinking pedagogy for a digital age, Routledge (2007).

15. J.D. Underwood, The impact of digital technology: a review of the evidence of the impact of digital technologies on formal education, British Educational Communications and Technology Agency (2009)

16. J. Martín-Gutiérrez, C.E. Mora, B. Añorbe-Díaz, A. González-Marrero, Virtual technologies trends in education, Eurasia Journal of Mathematics Science and Technology Education, 13(2), pp. 469-486 (2017). doi: 10.12973/eurasia.2017.00626a

17. F. Pucciarelli, A. Kaplan, Competition and strategy in higher education: Managing complexity and uncertainty, Business Horizons, 59(3), pp. 311-320 (2016). doi: 10.1016/j.bushor.2016.01.003

18. A.V. Kirillov, M.V. Vinichenko, A.V. Melnichuk, Y.A. Melnichuk, M.V. Vinogradova, Improvement in the learning environment through gamification of the educational process, International Electronic Journal of Mathematics Education, 11(7), pp. 2071-2085 (2016) 
19. V. Arkorful, N. Abaidoo, The role of e-learning, advantages and disadvantages of its adoption in higher education, International Journal of Instructional Technology and Distance Learning, 12(1), pp. 29-42 (2015)

20. B. Gan, T. Menkhoff, R. Smith, Enhancing students' learning process through interactive digital media: New opportunities for collaborative learning, Computers in Human Behavior, 51, pp. 652-663 (2015). doi: 10.1016/j.chb.2014.12.048

21. V.A. Devisilov, On the concept of the national educational policy in the field of security, Bezopasnost' v tehnosfere, 4, pp. 49-58, 5, pp. 56-64 (2008)

22. Official site of the Department «Ecology and industrial safety» BMSTU: 16 online lectures Life safety course, http://mhts.ru/study-uchebn-kursi-univer.html, last accessed 2019/10/29.

23. Official site of the Department «Ecology and industrial safety» BMSTU: Universitywide training courses: personal web pages of teachers, http://mhts.ru/study-uchebnkursi-univer.html, last accessed 2019/10/29. 